Peter C. Bisschop

\title{
After the Mahābhārata: On the Portrayal of Vyāsa in the Skandapurāna
}

Certain works of literature function as cultural hegemons. Their influence is so forceful that subsequent authors and literary traditions take their place only in relation to them. In the world of premodern South and Southeast Asia, the Mahäbhärata claims such a commanding position. There is an element of truth in the bold, much-cited claim in the first and the last books of the text, that "What is found here concerning dharma, the proper making of wealth, pleasure and final release, is to be found elsewhere, too, O bull-like heir of Bharata; but what is not found here is to be found nowhere." In addition to its master narrative of the catastrophic war between the Pāṇavas and the Kauravas, this status is to a large extent due to the epic's complex frame structure, which allowed for the nesting and integration of numerous additional narratives and didactic episodes that could be continuously expanded. ${ }^{2}$

Composed after the Mahābhārata, the Purānas constitute the most prolific genre of Sanskrit literature, displaying similarities in style and technique, but also departing from the epic in significant ways, particularly in terms of religious ideology, orientation, and scope. Recent work on the Skandapurāna - a text that was long held to be lost, but identified in early Nepalese palm-leaf manuscripts

1 MBh 1.56.33=18.5.38:

dharme cārthe ca kāme ca mokṣe ca bharatarșabha |

yad ihāsti tad anyatra yan nehāsti na tat kva cit ||

The translation is that of John Smith, trans., The Mahäbhärata. An Abridged Translation (London: Penguin, 2009). On the political status of the Mahābhārata in premodern South and Southeast Asia, see Sheldon Pollock, The Language of the Gods in the World of Men (Berkeley: University of California Press, 2006), 223-258.

2 On the frame story in the Indian context, see Michael Witzel, "On the Origin of the Literary device of the 'Frame Story' in Old Indian Literature,” in Hinduismus und Buddhismus. Festchrift für Ulrich Schneider, ed. Harry Falk (Freiburg: Hedwig Falk, 1987), 380-414.

Notes: This article is number 12 in the multi-authored series Studies in the Skandapurāna. For an overview of the series, see: https://www.universiteitleiden.nl/en/research/research-projects/ humanities/the-skandapurāna-project\#tab-1. Accessed January 8, 2020. Research for this paper has been supported by the Dutch Research Council (project no. 360-63-110) and the European Research Council (project no. 609823).

Ә Open Access. (C) 2021 Peter C. Bisschop, published by De Gruyter. (cc) BY-NC-ND This work is licensed under a Creative Commons Attribution-NonCommercial-NoDerivatives 4.0 International License.

https://doi.org/10.1515/9783110674088-003 
going back to the early ninth century CE - has brought to the fore the intricate layered history of Purānic text composition. ${ }^{3}$ A textual tradition dating to the sixth to seventh century and associated with the burgeoning Pāśupata movement, the Skandapurāna advocates Śiva devotion and provides a Śaiva model for viewing the cosmos and its affairs. It integrates all other deities into an overarching hierarchical structure in which Śiva, paired with his devoted wife Pārvatī, reigns supreme. Particularly striking in this regard is the text's inclusion of extensive new retellings of the myths of the three main manifestations of Viṣnu worshiped around the time of the Gupta period: Narasiṃha, Varāha, and Vāmana. ${ }^{4}$

While the incorporation and appropriation of narratives detailing the exploits of Viṣnu's manifestations in a Saiva text may hint at religious competition, the Skandapurāna's engagement with these narratives first of all reflects a strategic awareness of the cultural importance of these myths. In order to capture the audience's attention, the authors of this new Purāna had to engage with and address the narratives and deities that mattered to their intended audience. In a similar fashion, they had to find a way into the Mahābhārata, which provided the reference frame of the Brahminic lore in which they were operating. They did so in the very first chapter of the text, through the narrative frame describing the scene of the "original" telling of the Skandapurāna. In developing this frame, the authors of the text connect the first narration of the Skandapurāna to a central event in the Mahābhārata epic, namely the departure of Vyāsa's son Śuka from this world. The inclusion of this frame story is revealing, because with it, the authors not only

3 For a comprehensive study including the results of almost two decades of work on the critical edition, see Hans T. Bakker, The World of the Skandapurāna. Northern India in the Sixth and Seventh Centuries (Leiden: Brill, 2014).

4 Note, however, that they are not called avatāra in the text. See introduction to SP IV, 6. As was first observed by Phyllis Granoff, the Skandapurāna introduces a significant new element to Vișnu's demon-slaying manifestations: the god's attachment to the form he has taken on after he has killed the demon. The Skandapurāna raises the critical question of what happens to Viṣnu's demon-slaying manifestation after he has done the job. The Narasimpha episode, for example, shows him to be attached to his new man-lion form and Śiva, as the supreme God, has to intervene to make him return to his original form. Viṣnu is assigned the task of slaying demons, while Siva creates the circumstances that allow him to resume his true form afterwards. Siva thus becomes the true savior - of both the gods, who need Viṣnu to return to his original form, and Viṣnu himself, who is not able to revert to his true form on his own. See Phyllis Granoff, "Saving the Saviour: Siva and the Vaiṣnava Avatāras in the Early Skandapurāṇa," in Origin and Growth of the Purānic Text Corpus. With Special Reference to the Skandapurāna, ed. Hans T. Bakker, Papers of the 12th World Sanskrit Conference 3.2 (Delhi: Motilal Banarsidass, 2004), 111-138. The Skandapurāna's treatment of Viṣnu's three main manifestations forms the subject of the $\mathrm{PhD}$ project "Counter-Narratives: Parallel Themes in Vaiṣnava and Śaiva Mythology," undertaken by Sanne Mersch at Leiden University. 
engaged with and responded directly to the authority of the great Sanskrit epic but, as I will argue, ultimately tried to surpass it.

\section{The Introduction of Vyāsa in the Opening Chapter of the Skandapurāna}

While Vyāsa is well known as the composer and narrator of the Mahābhärata - a character who, at the same time, plays a key role in the epic "behind the scenes"5 his position in the Skandapurāna is reversed. No longer the all-knowing narrator, in the Skandapurāna Vyāsa is the pupil of Sanatkumāra, the first-born son of Brahmā. In this case it is Vyāsa who asks the questions, while Sanatkumāra provides the answers.

From the very start, the Skandapurāna recognizes the authority of the Mahābhārata: when the sages are assembled in Prayāga to bathe in the confluence of the Gangā and the Yamunā, they ask the Singer of Ancient Lore (paurānika sūta) to tell them about "the birth of the wise Kārttikeya, which equals the story of the Bhārata (Mahābhārata) and surpasses the Purāṇa.”6

The unnamed sūta starts by describing the scene of the original setting of the first narration of the birth of Skanda-Kārttikeya:

"After the noble Śuka had gone to the supreme station because of his desire for release, Vyāsa, tormented by grief for his son, saw Tryambaka (Śiva). Having seen the Great Lord, his pain disappeared.

"Then, while roaming the worlds, the sage (Vyāsa), the son of Satyavatī, saw Sanatkumāra, the first-born son of Brahmā, granter of boons, furnished with yogic power, on the peak of Mt. Meru, standing there like fire, in his vimāna which was brilliant like the sun, surrounded by noble sages who were perfected in yoga, furnished with ascetic power and masters of all sciences; he looked like the four-headed god (Brahmā).

"After Vyāsa had seen that very great being, the sage, dwelling there like the Grandfather (Brahmā) in person, he praised him with the highest devotion.

5 Cf. Alf Hiltebeitel, Rethinking the Mahābhārata. A Reader's Guide to the Education of the Dharma King (Chicago: Chicago University Press, 2001), 32-91, and, for a critique of the same, James L. Fitzgerald, “The Many Voices of the Mahābhārata," Journal of the American Oriental Society 123, no. 4 (2003): 815-817.

6 SP 1.11:

bhāratākhyānasadṛśam purāṇād yad višișyate | tat tvā prcchāma vai janma kārttikeyasya dhïmatah /| 
"Then the son of Brahmā (Sanatkumāra), embraced with affection the very mighty Vyāsa, who had approached, and he delivered an auspicious speech.

“'You have arrived, o knower of Dharma, by good fortune, freed from sorrow because of the grace of Parameśvara. Ask and I will tell you!’”7

In response to Sanatkumāra's offer, Vyāsa asks him about something that has long bothered him: how is it possible that Skanda (Kumāra/Kārttikeya) can be the son of Rudra and of Vahni, of Gañgā, Umā, Svāhā, Suparṇī, and the Mothers, as well as of the Kṛttikās? ${ }^{8}$ This question is remarkable, because it is after all Vyāsa himself who has given us at least three different accounts of Skanda's birth in his own Mahābhārata. ${ }^{9}$ Sanatkumāra promises to tell it all, and this promise initiates the telling of the Skandapurāna.

7 SP 1.15-22:

mumukșayā paraṃ sthānaṃ yāte śubhamahātmani | sutaśokābhisaṃtapto vyāsas tryambakam aikșata /I dṛștvaiva sa maheśānaṃ vyāso 'bhūd vigatavyathaḥ | vicaran sa tadā lokān muniḥ satyavatīsutaḥ /I meruśrnige 'tha dadṛse brahmaṇah sutam agrajam | sanatkumāram varadam yogaiśvaryasamanvitam /| vimāne ravisaṃkāśe tișțhantam analaprabham / munibhir yogasamsiddhais tapoyuktair mahātmabhih // vedavedāngatattvajñaị sarvadharmāgamānvitaih | sakalāvāptavidyais tu caturvaktram ivāvrtam // dṛșțā tam sumahātmānaṃ vyāso munim athāsthitam / vavande parayā bhaktyā sākṣād iva pitāmaham // brahmasūnur atha vyāsaṃ samāyātam mahaujasam / parișvajya paraṃ premnā provāca vacanaṃ śubham // diștyā tvam asi dharmajña prasādāt pārameśvarāt | apetaśokah samprāptaḥ prcchasva pravadāmy aham //

8 SP 1.24-26:

kumārasya katham janma kārttikeyasya dhīmatah | kiṃnimittaṃ kuto vāsya icchāmy etad dhi veditum // kathaṃ rudrasutaś cāsau vahnigangāsutaḥ katham / umāyās tanayaś caiva svāhāyāś ca kathaṃ punạ̣| suparṇyās cātha māț̣ṇ̄ām kṛttikānāṃ kathaṃ ca saḥ // kaś cāsau pūrvam utpannaḥ kị̣tapāḥ kaś ca vikramaḥ I bhūtasaṃmohanam hy etat kathayasva yathātatham /|

9 For the various and conflicting birth stories in the Mahābhārata, see Richard Mann, The Rise of Mahāsena. The Transformation of Skanda-Kārttikeya in North India from the Kușāna to Gupta Empires (Leiden: Brill, 2012), 18-21, 79-100. 
This frame narrative is significant in several respects. First of all, it shows that the text engages strategically with a key event of the great epic. It concerns an episode that, from the perspective of its supposed author, Vyāsa, is one of the most troubling of all: his son's departure from this world in his quest for liberation (mokșa). Seen in this light, it is not so surprising that Vyāsa should ask about the miraculous birth of another son, Skanda, since his own son is still on his mind. ${ }^{10}$ While Vyāsa, being the archetypical composer of Brahminic lore, is traditionally credited with many compositions, including the Veda, the Mahābhārata, and the Purānas, ${ }^{11}$ on this occasion he is presented in an opposite role, as the dedicated

10 It is even possible to establish a link between Vyāsa's questions at the start of the Skandapurāna (SP 1.24-26, cited above) and those of Yudhișthira to Bhīșma at the start of the Śuka episode of the Mahābhärata (MBh 12.310.1-5), which likewise center around the mystery of his birth:
kathaṃ vyāsasya dharmātmā śuko jajñe mahātapāḥ | siddhim ca paramām prāptas tan me brūhi pitāmaha /I kasyāṃ cotpādayām āsa śukaṃ vyāsas tapodhanaḥ | na hy asya jananim vidma janma cāgryam mahātmanah // kathaṃ ca bālasya sataḥ sūkșmajñāne gatā matị̣ | yathā nānyasya loke 'smin dvitìyasyeha kasya cit /I etad icchāmy ahạ̣ śrotum vistareṇa mahādyute | na hi me tṛtir astīha śṛnvato 'mṛtam uttamam // māhātmyam àtmayogạ̣ ca vijñānaṃ ca śukasya ha | yathāvad ānupūrvyeṇa tan me brūhi pitāmaha //

As James Fitzgerald has pointed out to me (personal communication), both sons (Śuka and Skanda) share a similar kind of conception: Śuka is born from the seed of Vyāsa spilled on the fire sticks (see below) and Skanda is born from the seed of Śiva ejected into the fire (Agni).

11 Cf. Bruce Sullivan, Kṛṣna Dvaipāyana Vyāsa and the Mahābhārata: A New Interpretation (Leiden: Brill, 1990), 1; also Ludo Rocher, The Purānas, A History of Indian Literature 2.3 (Wiesbaden: Harrassowitz, 1986), 45-48, on Vyāsa as the composer of the "Purānasaminitā." For Vyāsa’s own pedigree, see Giorgio Bonazolli, "Purāṇic Paramparā,” Purāṇa 22 (1980): 33-60. His table I (pp. 36-39) indicates that the majority of the Purānas follow a tripartite scheme: Brahmā > sage (e.g. Vasișṭha, Sanatkumāra, or Nārada) > Vyāsa.

The name Vyāsa, as is well known, means "arranger," hinting at his role as a "transmitter" or "tradent" of Brahminic lore. For the term "tradent," used by scholars of Jewish rabbinic literature to refer to the "noncreative" role of the Rabbinic sages in the transmission of rabbinic literature, see Martin S. Jaffee, "Rabbinic Authorship as a Collective Enterprise," in The Cambridge Companion to the Talmud and Rabbinic Literature, eds. Charlotte Elisheva Fonrobert and Martins S. Jaffee (New York: Cambridge University Press, 2007), 17-37. On this role of Vyāsa, see Peter C. Bisschop, "Vyāsa's Palimpsest: Tracking Processes of Transmission and Re-creation in Anonymous Sanskrit Literature,” in Perspectives on Lived Religion: Practices - Transmission Landscape, eds. N. Starling, H. Twiston Davies, and L. Weiss (Leiden: Sidestone Press, 2019), $165-172$. 
student of the mysterious figure of Sanatkumāra, the first-born son of Brahmā. I argue that through the introduction of this frame narrative, the composers of the Skandapurāna were aiming to rewrite the received Mahābhärata tradition ${ }^{12}$ and present the audience with a higher perspective. By starting with a new and unknown narrative that concerns the composer of the epic at his most vulnerable, the Skandapurāna authors added an additional layer of interpretation that, as we shall see, turned Vyāsa into a dedicated Pāśupata adept.

To properly appreciate the significance of the Skandapurāna's adoption of this frame story, we should first of all take a look at the relevant passage in the Mahābhārata, in which Suka departs from this world and Vyāsa is left behind, grieving for his son. The story is told in book 12 of the epic, the Säntiparvan "The Book of Peace."13 Vyāsa had received Śuka from Śiva after performing austerities on Mt. Meru. He had asked for a son who would be equal in power to the five elements. The son is born when Vyāsa sheds his semen on the sacrificial fire sticks ( $\operatorname{araṇi})$ at the sight of the beautiful Apsaras Ghṛtācī (MBh 12.310-311). Suka first learns the mokșadharma "Teachings on Liberation" from Vyāsa, then from king Janaka, and finally from Nārada $(M B h 12.312-319) .{ }^{14}$ In the end, Suka resolves to abandon his body and attain final liberation. A long description of his ever-higher journey toward liberation follows, in which he identifies himself with Brahman (MBh 12.319-320). Vyāsa tries to follow him through yoga but he ends up realizing that Suka has left him behind, after which he sits down in grief. ${ }^{15}$ At

12 By "Mahābhārata tradition" I mean not only the text as we have it, but also the cultural awareness that comes with it. This involves multiple sources: from commentaries, to performance traditions, to material representations, as well as new compositions that refer to it, such as - in the present case - the Skandapurāna.

13 The story of Śuka in the Mahābhārata has been studied by a number of scholars, including V.M. Bedekar, "The Story of Śuka in the Mahābhārata and the Purānas: A Comparative Study," Purāna 7 (1965): 87-127; C. MacKenzie Brown, "Modes of Perfected Living in the Mahābhärata and the Purānas: The Different Faces of Suka the Renouncer," in Living Liberation in Hindu Thought, eds. Andrew O. Fort and Patricia Y. Mumme (Albany: State University of New York Press, 1996), 157-183; David Shulman, The Hungry God. Hindu Tales of Filicide and Devotion (Chicago: University of Chicago Press, 1993), 108-146; and Hiltebeitel, Rethinking the Mahābhārata, 278-322.

14 In the light of the Skandapurāna's account, it is noteworthy that Nārada first of all refers to the teachings on renunciation and liberation as they were taught by Sanatkumāra $(M B h$ 12.316.5-19).

15 MBh 12.320.27:

mahimānam tu taṃ dṛșțā putrasyāmitatejasaḥ | niṣasāda giriprasthe putram evānucintayan /I 
this moment, Siva appears before him to console him (MBh 12.320.31-37). The compound used to express Vyāsa's state of mind, putraśokābhisaṃtapta ("tormented by grief for his son," $M B h$ 12.320.32c), is almost identical to that used by the Skandapurāṇa to describe the very same moment (sutaśokābhisaṃtapta, SP 1.15c). It functions as a clear marker linking the two texts. Śiva reminds Vyāsa that he had given him a son who would master the elements, in accordance with Vyāsa's own request. His son has won eternal fame. To console Vyāsa, he gives him Śuka in the form of a shadow as his constant companion. ${ }^{16}$

\section{The Bhāgavata Character of the Mahābhārata}

At this point, we need to ask the question: why did the authors of the Skandapurāna select this particular episode to frame the original narration of the Skandapurāna? I can see at least three reasons, which are, to a certain extent, all connected.

First of all, the position of the Mahäbhärata as the founding epic of Sanskrit culture is undeniable. For new compositions to gain a mark of authority, it was thus good strategy to connect themselves in one way or another with events narrated in the great epic. The specific episode selected by the authors of the Skandapurāna is particularly fitting because it concerns one of the most moving moments in the life of the author of the text, namely his son's departure for mokșa. To claim the authority of the epic, what better episode than this one, in which the author himself is distraught at his son's reaching the final state? It perfectly captures the conflict between the ideals of action (pravrtti) and withdrawal (nivrtti) that are at the heart of the epic. Moreover, the episode has a Saiva connection, because Vyāsa had received his son from Śiva after practicing intense asceticism. This motif paved the way for linking it to the Śaiva Purāna about to be told.

A second reason, I argue, has to do with the Bhāgavata character of the Mahäbhärata. ${ }^{17}$ While the epic may not have started out as a religious document, it had been infused with a Kṛṣna and Nārāyana theology by the time of its written Gupta redaction, which is what most scholars see as the form of the text as we

16 MBh 12.320.37:

chāyāṃ svaputrasadṛsīm sarvato'napagāṃ sadā |

drakșyase tvam ca loke 'smin matprasādān mahāmune //

17 I use the term "Bhāgavata" in a general sense to refer to early traditions of Vișnu worship. Cf. Gérard Colas, "Bhāgavatas,” in Brill's Encyclopedia of Hindusim, vol. 3, eds. Knut Jacobsen et al. (Leiden: Brill, 2011), 295-301. 
find it more or less represented in the main text of the Poona critical edition. ${ }^{18}$ This Bhāgavata character is particularly evident in the teachings of the Bhagavadgitā (MBh 6.23-40) just before the start of the central battle, as well as various other Kṛ̣̣na-, Viṣnu- and Nārāyaṇa-related teachings strategically placed across different parts of the epic, but in particular in the - undeniably sectarian Nārāyanīyaparvan (MBh 12.321-339). ${ }^{19}$ It may be precisely because of the insertion of Nārāyaṇa theology that many manuscripts of the individual books of the epic start with the celebrated mañgala invocation of Nara and Nārāyaṇa:

nārāyaṇaṃ namaskṛtya naram caiva narottamam /

devīị sarasvatīm caiva tato jayam udìrayet $\|^{20}$

18 For a general overview, see James L. Fitzgerald, "Mahābhārata," in Brill's Encyclopedia of Hinduism, vol. 2, eds. Knut Jacobsen et al. (Leiden: Brill, 2010): 72-94. Cf. his characterization of the epic (p. 92): "The text of the Mahābhārata at the close of the Gupta era describes a particular episode of world history at a particular juncture of the flow of time in the cosmos, one of the occasional severe crises that arise in terrestrial affairs and call for apocalyptic divine sanction - god's descending in disguised form into terrestrial affairs and marshalling divine and human forces against demonic energies that harm the fundamental welfare of all souls in the universe. In this text's teachings, solace and hope are offered to all weary souls by showing that all things are centered upon the reality and activity of the god Nārāyaṇa-Viṣnu, who presides over the creation, sustenance, and then destruction of the universe against the tableaux of the vast movements of time that are now seen." See also John Brockington, The Sanskrit Epics (Brill: Leiden, 1998), 256-302.

19 Reinhold Grünendahl characterizes the overall incorporation of a Nārāyaṇa scheme in the final redaction of the Mahābhārata as follows: "Die Nārāyaṇa-Theologie des Nārāyaṇiya und das ihr zuzuordnende Ideenprofil manifestieren sich an diversen, über das Mahābhärata verteilten Stellen, die zusammen eine Art Rahmen bilden. Mittels dieses Rahmens hat die in ihm sich artikulierende Schule der »epischen Pāñcarātrins« ihre theologischen Vorstellungen offenbar planmäßig in das Mahābhārata integriert [. . .] und dem Epos als Ganzes damit zugleich ihre unverwechselbares Gepräge gegeben.” See Reinhold Grünendahl, "Zur Stellung des Nārāyaṇiya im Mahābhārata,” in Nārāyaṇiya-Studien, ed. Peter Schreiner (Wiesbaden: Harrassowitz, 1997), 197-240; also Reinhold Grünendahl, “On the Frame Structure and 'Sacrifice Concept' in the Nārāyaṇiya and Tīrthayātrā Sections of the Mahābhārata, and the Craft of Citation," Zeitschrift der Morgenländischen Gesellschaft 152, no. 2 (2002): 309-340. This is not to deny that the Mahābhärata contains teachings involving Siva as well, but when it comes to the epic's overarching model, it is clearly centered around Kụ̣̣na-Viṣnu-Nārāyaṇa. The Anuśāsanaparvan in particular has a number of significant Śaiva episodes. For a structural study of Śiva in the Mahābhārata, see Jacques Scheuer, Śiva dans le Mahābhārata (Paris: Presses Universitaires de France, 1982); also Peter C. Bisschop, “Śiva," in Brill's Encyclopedia of Hinduism, vol. 1, eds. Knut Jacobsen et al. (Leiden: Brill, 2009), 744-746.

20 On the other hand, as observed by V. S. Sukthankar in the prolegomena to the edition of the $\bar{A}$ diparvan (p. iii), this stanza is missing from the Southern manuscripts. See also Sylvain Lévi, “Tato jayam udirayet," trans. L. G. Khare, Annals of the Bhandarkar Oriental Research Institute 1, no. 1 (1918-19): 13-20. No less important than the specific form of the epic after its Gupta redaction 
"Honour first Nārāyaṇa, and Nara, the most excellent of men; honour too Sarasvatī the goddess; then proclaim the Tale of Victory!"21

A text like the Skandapurāna, which advocates a Śaiva perspective, would have been confronted with this situation and have to address it in one way or another. In this connection, it seems significant that the Śuka episode of the Mahābhārata (12.310-320) precedes exactly the teachings of the Nārāyaniyyaparvan (MBh 12.321-339). We have seen how the Śuka episode forms the starting point for the telling of the Purāna. In the chapters that follow, in fact, some of the central doctrines concerning Rudra in the Nārāyanìya are taken up, but their message is turned around. This concerns in particular the teaching that Brahmā is the father of Rudra, which is a doctrine characteristic of the Nārāyaniyya, but spectacularly overturned by the account of creation given in the Skandapurāna. Chapter 3 of the Skandapurāna tells how Brahmā was born in the Cosmic Egg and in his ignorance did not realize that he had a father. Thinking himself to be alone at the beginning of time, he hears a voice addressing him with the words "son, son!” (putra putra), which turns out to be that of Siva. Brahmā takes refuge with Siva, who grants him the position of demiurge and ruler over the worlds. ${ }^{22}$ Various other elements in the Skandapurāna likewise show that the authors of

is the question to what extent the transmission and control of the Mahäbhärata may have been in the hands of Bhāgavata communities. The mangala verse of the Northern manuscripts certainly points in such a direction. The inclusion and general acceptance of the Harivamśa, treating of the life of Kṛ̣na, as an appendix (khila) to the Mahābhārata suggests a Bhāgavatadominated environment of Mahābhärata transmission as well. For the status of the Harivamiśa as an "appendix" to the Mahābhārata, see Andre Couture, "The Harivamśa: a Supplement to the Mahābhārata," Journal of Vaishnava Studies 4, no. 3 (1996): 127-138; Freda Matchett, "The Harivamiśa: Supplement to the Mahābhārata and Independent Text," Journal of Vaishnava Studies 4, no. 3 (1996): 139-150.

21 Trans. Smith, The Mahābhārata.

22 SP 3.4-7:

purā brahmā prajādhyakșah aṇde 'smin samprasūyate |

so 'jñānāt pitaraṃ brahmā na veda tamasāvrtah /I

aham eka iti jñātvā sarvāṃl lokān avaikșata |

na cāpaśyata tatrānyam tapoyogabalānvitah ||

putra putreti cāpy ukto brahmō śarveṇa dhìmatā |

praṇataḥ prāñjalir bhūtvā tam eva śaraṇam gatạ̣ //

sa dattvā brahmaṇe śambhuḥ srașțrtvaṃ jñānasaṃhitam /

vibhutvaṃ caiva lokānām antardhe parameśvarah /| 
the text were familiar with and opposed to the teachings of the Nārāyañiya. ${ }^{23}$ By putting the narrative frame in relation to the Suka episode that directly precedes the Nārāyaniya, the authors were able to take control of the epic's religious teachings and bring in their own Śaiva perspective. ${ }^{24}$

A final reason for selecting this episode to frame the Saiva teachings of the Skandapurāna is connected to the nature of the subject. The Suka episode centers around the ideal of mokșa, final liberation, realized by renunciation of life in total. Suka is the quintessential yogin and renouncer. The Nārāyañiya, which follows upon the story of Suka, teaches that devotion to lord Nārāyana is the means of bhakti to achieve the same goal. The Skandapurāna, aside from being a foundational work that integrates Śaiva- and non-Śaiva mythology in a comprehensive manner, also teaches a theology and a corresponding path toward liberation. This path centers around the Pâsupata ideal of union with Siva (śivasāyujya) reached through complete devotion (bhakti) to Śiva. As such, the way of mokșa turns out to be the final teaching of the Skandapurāna as well. And it is this Pāśupata path to liberation that is ultimately taught to Vyāsa, the father who has lost his own son in the quest for final liberation. To understand how this links up with the narrative frame of the Skandapurāna, we now have to leave aside the main body of the work and turn to the conclusion of the text.

\section{Vyāsa the Pāśupata}

The final ten chapters of the Skandapurāna are dedicated to the teaching of Pāśupata yoga. ${ }^{25}$ Ultimately, this yoga involves a practice of what is called utkrānti ("proceeding upwards," "stepping out," or "yogic suicide," as it is sometimes

23 The relations between the Nārāyanīya and the Skandapurāna are addressed in my forthcoming study: "Rudra-Śiva in the Nārāyaṇiya and the Rejoinder of the Skandapurāna," in The Nārāyaṇiya: Reconsidering an Epic and Its Contexts, eds. Robert Leach and Angelika Malinar. 24 On the connection between the Nārāyaniyya and the Śuka episode, see Alf Hiltebeitel, “Mokșa and Dharma in the Mokșadharma," Journal of Indian Philosophy 45 (2017): 749-766.

25 For the Skandapurāna's connections with the Pāśupata movement, see Peter C. Bisschop, Eary Saivism and the Skandapurāna. Sects and Centres (Groningen: Egbert Forsten, 2006), 37-50; Bakker, The World of the Skandapurāna, 137-153; and Elizabeth A. Cecil, "Mapping the Pāśupata Landscape: Narrative, Tradition, and the Geographic Imaginary,” The Journal of Hindu Studies 11, no. 3 (2018): 285-303. Although the last ten chapters as a whole may be referred to as "Pāśupatayogavidhi," the text also addresses and criticizes the rival system of Sāṃkhya-Yoga. The Pāśupata teaching proper starts at $S P_{\mathrm{Bh}} 180$. 
referred to). ${ }^{26}$ "Suicide" brings with it a whole set of Western ideas that are not applicable; I therefore prefer to refer to utkrānti as "liberational death." It is a way of taking control of death, which awaits us all, and turning it into the key to liberation.

The practice is described in detail in the text's penultimate chapter $\left(S P_{\mathrm{Bh}}\right.$ 182); it is performed through a process of actively blocking the breath and pushing it upwards through the cranium. This voluntary death brings about final liberation through merging with Siva $\left(S P_{\mathrm{Bh}}\right.$ 179.46-47ab):

sadaivaṃ dhyāyato ${ }^{27}$ vyāsa tad aiśvaryaṃ pravartate |

yena șadvimśakam buddhvā hṛdayastham maheśvaram //

svecchayā svatanum tyaktvā tasminn eva pralìyate |

"As one constantly meditates like this, Vyāsa, that lordship comes about, through which, after realizing the twenty-sixth [principle], Maheśvara, who resides in the heart, [and] abandoning one's own body according to one's own will, one is absorbed in Him [i.e. Maheśvara].”

The practice is the preserve of the Pāśupata yogins who, during life, abide by the regime of the Pāśupata observance of bathing in ashes $\left(S P_{\mathrm{Bh}} 182.53\right)$ :

evaṃ pāśupatā viprā niṣkalaṃ taṃ maheśvaram |

yogād āviśya mucyante punarjanmavivarjitāh /|

"In this way the Pāśupata brahmins are released, freed from rebirth, after reaching the undivided Maheśvara through yoga.”

In several respects, one may argue, the practice of utkrānti forms the counterpart of the yogic ideal of retreat from bodily existence that was realized by the renunciant Śuka. For example, in $S P_{\mathrm{Bh}} 181.29-30 d$, it is said:

nirmamā yogaviduṣaḥ śaṃkaravratam āsthitāḥ |

gacchanti svatanuṃ tyaktvā hitvā māyāṃ paraṃ padam /I

"The knowers of yoga, free from possession, abiding by the observance of Śamkara, reach the supreme state, after abandoning the body, leaving behind material existence."

26 On utkrānti in the context of traditions of yoga, see Peter Schreiner, "Yoga - Lebenshilfe oder Sterbetechnik?” in Hinduismus-Reader, ed. Angelika Malinar (Göttingen: Vandenhoeck \& Ruprecht, 2009), 137-148; David Gordon White, “Utkrānti: From Epic Warrior’s Apotheosis to Tantric Yogi's Suicide," in Release from Life - Release in Life. Indian Perspectives on Individual Liberation, ed. Andreas Bigger et al. (Bern: Peter Lang, 2010), 291-302; and James Mallinson and Mark Singleton, Roots of Yoga (London: Penguin, 2017), s.v. "yogic suicide (utkrānti)."

27 Corrected. Bhațtarāī's edition reads dhyayato. All of the following quotations from the final ten chapters of the text refer to the editio princeps of Bhațtarāi $\left(S P_{\mathrm{Bh}}\right)$. 
This recalls Suka's reaching of the highest state after giving up his body. Sanatkumāra indeed refers to the practice as "voluntary renunciation of the body" (svacchandatanusaṃtyāga, $S P_{\mathrm{Bh}}$ 182.26a). The main difference, of course, is that Śuka did not take up the Pāśupata observance taught here, but followed his own path of yoga.

Although the Pāsupata yoga is described in these last chapters in a more or less general way, at several key moments in the instruction, Sanatkumāra addresses his teaching to Vyāsa personally, who affirms that he has understood it. The two share a guru-śișya relationship, as is made explicit for example in $S P_{\mathrm{Bh}}$ 182.9:
evamuktạ̣ sa śișyena vyāsena sumahatmanā |
kathayāmāsa viprendrạ̣ śivasiddhāntaniścayam /|
"Thus addressed by his pupil, the very noble Vyāsa, the chief of brahmins (Sanatkumāra) explained the ascertainment of the dogma of Śiva.”

And in $S P_{\mathrm{Bh}}$ 182.50, Sanatkumāra emphatically instructs Vyāsa to practice the Pāśupata observance himself:
sa tvaṃ vyāsa mahābuddhe caran pāsupatam vratam /
mahādevaparo bhūtvā jñānam etad avāpnuhi /I
"You, Vyāsa, very intelligent one, must practise the Pāśupata observance. Having become dedicated to Mahādeva, you will attain this knowledge.”

It is worth taking a moment to step back and reflect on the implications of the bold move expressed here; for with it, the composers of the Skandapurāna have managed to turn the celebrated author of the epic Mahābhārata into a dedicated Pāśupata ascetic.

The same is restated once more, in even stronger terms, in the text's final chapter ( $S P_{\mathrm{Bh}}$ 183.53ff.). Here Sanatkumāra once again confirms that he has taught him the supreme yoga and that Vyāsa will attain the highest liberation after realizing the supreme lord. In this connection, he adds several prophesies about Vyāsa as well: he will become a yogin, he will compose the Purāna, he will divide the Veda into four, he will institute the Dharmas, and finally, he will attain absorption in Î́vara $\left(S P_{\mathrm{Bh}} 183.59 \mathrm{c}-60 \mathrm{~b}\right)$ :

\section{bhasmavrataṃ ca samprāpya paśupāśavimocanam // sāịkarajñānasampannaḥ îsvare layam āpsyasi |}

\footnotetext{
"After completing the ash-observance, which releases from the bondage of a bound soul, you will attain absorption in the lord, being endowed with the knowledge of Samkara."
} 
Several of these prophesies, such as his composition of the Purāna and his division of the four Vedas, fit with what we know about Vyāsa from other sources, but the notion that he achieves salvation through Pāśupata yoga is unique to the text and introduces a radically new perspective. It reorients the audience's perception of the identity of the author of the great epic.

The passage concludes as follows $\left(S P_{\mathrm{Bh}} 183.60 \mathrm{~cd}-62\right)$ :

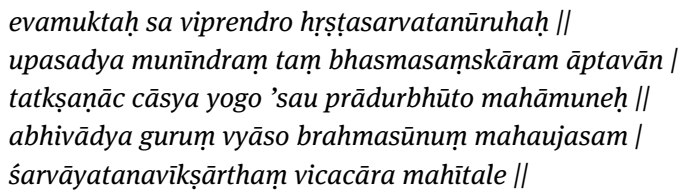

"Thus addressed, that best of brahmins (Vyāsa), with all his hair bristling with joy, approached the supreme sage and received the consecration with ashes; at that moment that yoga appeared to the great sage. After Vyāsa had saluted his preceptor, the son of Brahmā, of great might, he roamed the earth to see the abodes of Samkara.”

These verses contain significant initiatory terminology, such as "consecration with ashes" (bhasmasamskāra) and "preceptor" (guru), once again indicative of the guru-śişya relationship between the two, and leave no doubt that Vyāsa is being initiated in the Pāśspata observance by Sanatkumāra. The latter is thus not only the narrator of the Purāna's stories, but ultimately his spiritual guide, a Pāśupata teacher who directs Vyāsa on the Pāśupata path to liberation. ${ }^{28}$

\section{The Mahābhārata's Cultural Hegemony and What It Meant for Subsequent Compositions}

Having shown how the authors of the Skandapurāna capitalized on the Mahābhärata epic by turning its composer into a dedicated student of Sanatkumāra and, ultimately, a Pāśupata liberation-seeker, I want to conclude with a few observations on the position of the Mahäbhärata in the wake of the

28 As for Sanatkumāra's adhikāra to do so, in SP 175.35-36, Sanatkumāra tells Vyāsa that he received instruction in Pāśupata yoga from Śiva himself, which qualifies him as a Pāśupata teacher:

yadāhaṃ devadevena svayam eva jagatsrijāl svayogaṃ śambhunā vatsa grāhito gatasaṃsayaḥ/l tadā șadvimịśakạ̣ tattvaṃ jñātvā sarvagam ìśvaram/ vimukto yogasamsiddho 'ham mohavivarjitahl/ 
Gupta period. In particular, I would like to raise the question to what extent its final Bhāgavata orientation may have affected the form and narration of subsequent compositions by different Brahminic religious communities, specifically the works of professed Vaiṣnava and Saiva identification. Naturally, this is a huge topic that I cannot address here in all its detail, but I do think it deserves more attention than it has received so far.

A good starting point for comparison is the composition of a new class of literature dedicated to the rituals, activities, and attitudes of devotion to be adopted by worshippers of Viṣnu and Śiva, composed in the centuries after the completion of the Mahābhärata. For this, we have the Viṣnudharma on the one hand and the Sivadharma (or Sivadharmaśāstra) on the other. While the precise dates of these texts remain open for discussion, there can be no doubt that both of them are postepic compositions. ${ }^{29}$

The Vișudharma emphatically styles itself as a direct continuation of the Mahābhārata epic. This can already be seen from its opening verse, which - after the Bhāgavata mantra om namo bhagavate vāsudevāya "Om, homage to the Blessed Vāsudeva!” - commences with the same benedictory verse invoking Nara and Nārāyaṇa that also heads manuscripts of the Mahābhārata. ${ }^{30}$ The second verse of the text is identical to the final verse of the entire Mahābhārata, asking the rhetorical question: "he who learns the Bhārata, what need has he of sprinkling with the waters of Puskara?"31 By starting the work with a combination of the opening and concluding verse of the Mahābhärata, the Viṣnudharma presents itself as a direct continuation of the epic. These verses can be seen as further markers of the Bhāgavata-controlled transmission of the Mahābhārata at the time.

29 The Vișnudharma has been edited by Reinhold Grünendahl, Vișnudharmāḥ. Precepts for the Worship of Vișnu, 3 vols. (Wiesbaden: Harrassowitz, 1983-1989). The study of the Sivadharmaśāstra has been taken up only relatively recently. For an introductory survey, with references to recent editions and studies, see Peter C. Bisschop, Universal Saivism. The Appeasement of All Gods and Powers in the Śāntyadhyāya of the Śivadharmaśāstra (Leiden: Brill, 2018), 1-27.

30 The same verse also appears at the beginning of several Purānas, as well as the Harivamiśa, which thus likewise present themselves as continuations of the Mahābhārata.

$31 M B h$ 18.5.54 (also $M B h$ 1.2.242):

dvaipāyanaușțhapuțaniḥștam aprameyam, puṇyaṃ pavitram atha pāpaharaṃ śivaṃ (ViDh: śubhaṃ) ca I

yo bhārataṃ samadhigacchati vācyamānaṃ, kiṃ tasya pușkarajalair abhișecanena ||

On this verse, see James Hegarty, "What Need Has He of the Waters of Puṣkara? The Narrative Construction of tìrtha in the Sanskrit Mahābhārata," in Battle, Bards and Brāhmins, ed. John Brockington, Papers of the 13th World Sanskrit Conference 2 (Delhi: Motilal Banarsidass, 2012): 129-156. 
The same strategy is continued in the frame narrative of the Viṣnudharma. The chief narrator of the text is Saunaka, who plays a key role in the outermost narrative frame of the Mahābhārata's elaborate frame structure. The text commences with the visit of Śaunaka and other sages to Śatānika, the son of Janamejaya, following his royal consecration. This setting once again evokes the Mahābhārata, for it was at Janamejaya's snake sacrifice that Vyāsa's Mahābhārata was told by Vaiśampāyana and heard by Ugraśravas. ${ }^{32}$ Satānīka requests Śaunaka to tell him about Nārāyaṇa, referring to the fact that his ancestors had regained their kingdom by turning to Nārāyaṇa, and that Nārāyaṇa had saved the life of his stillborn grandfather Parīkșit. ${ }^{33}$ In other words, the Viṣnudharma emphatically places itself in direct relation to the Mahābhārata and, more importantly, presents the epic as a history in which the protagonists were ultimately successful because of their devotion to Nārāyana. This further fuels the Bhāgavata perspective of the epic. Furthermore, the teachings of the Viṣnudharma themselves have much in common with those of the Nārāyaniyaparvan of the Mahābhārata. ${ }^{34}$

If we turn to the narrative frame of the Sivadharma, however, the model is radically different. In a situation in which the canon of the Mahābhārata was in the hands of the Bhāgavatas, which allowed little room for the upcoming Śaiva traditions to claim their place, the Sivadharma adopted a model that overruled anything that had been taught before, for the teaching of the Sivadharma is fundamentally presented as the teaching of god Siva himself. He is, in other words, both subject

32 When the sages headed by Śaunaka perform a twelve-year sacrifice in the Naimișa forest, the sūta Ugraśravas appears and tells the sages about how he attended the snake sacrifice of Janamejaya, where he heard the Mahābhārata composed by Vyāsa being recited by Vaiśampāyana.

33 Viṣnudharma 1.1-6:

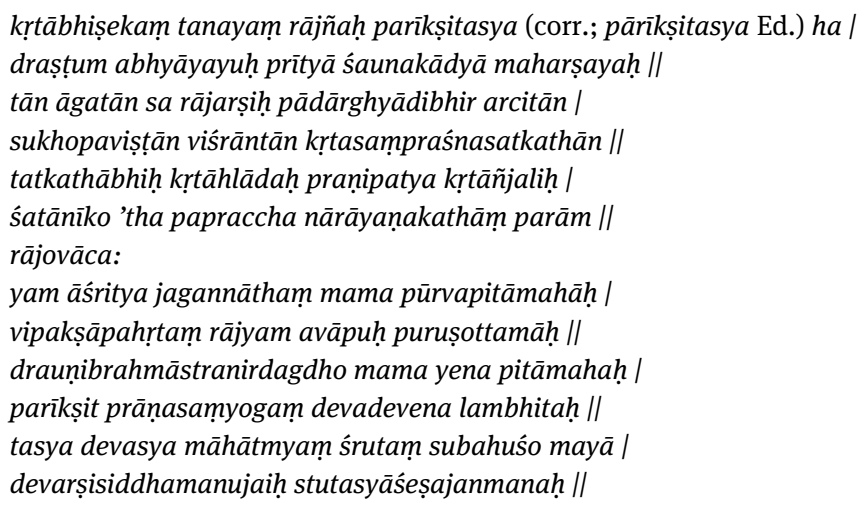

The story of the resurrection of Parikșit is told in MBh 14.65-70.

34 See Grünendahl, “Zur Stellung des Nārāyaṇiya im Mahābhārata,” 234-235. 
and object of the teaching, just like Kṛ̣na in the Bhagavadgittā. The Sivadharma is presented in its opening chapter as a dialogue between Nandikeśvara and Sanatkumāra (and other sages) on Mt. Meru, but Nandikeśvara tells Sanatkumāra that it was Śiva himself who had originally revealed the teaching of his own worship to Pārvatī, Skanda, Nandikeśvara, and other gods. ${ }^{35}$ The text ends with an account of how the teaching came to the human world, stating that Sanatkumāra passed the teaching onto "a Śaiva devotee of the Candrātreya lineage" and that Candrātreya extracted the essence from it and taught the Sivadharma in its present twelve chapters. ${ }^{36}$ This model corresponds to that of the tantrāvatāra or "descent of the Tantra," which became highly effective and was widely adopted in the early medieval period. ${ }^{37}$

The Sivadharma's model presents one way of circumventing the issue of the Bhāgavata canonization of the Mahābhārata. It effectively involved a complete disregard of the epic, instead introducing the very successful model of instruction by

35 Śivadharmaśāstra 1.10-11:

śrūyatām abhidhāsyāmi sukhopāyaṃ mahatphalam |

paramaṃ sarvadharmāṇām śivadharmaṃ śivātmakam ||

śivena kathitam pūrvaṃ pārvatyāh șaṇmukhasya ca I

gaṇānāṃ devamukhyānāṃ asmākaṃ ca viśeșataḥ //

Text as quoted in Bisschop, Universal Śaivism, 6-7, from Nina Mirnig's draft edition of the first chapter.

36 Śivadharmaśāstra 12.102:

sārāt sāraṃ samuddhṛtya candrātreyeña dhīmatā |

uktạ̣ ca dvādaśādhyāyaṃ dharmaśāstraṃ śivātmakam /|

Text as constituted in Florinda De Simini, Of Gods and Books. Ritual and Knowledge Transmission in the Manuscript Cultures of Premodern India (Berlin: de Gruyter, 2016), 62, n. 173.

37 See Dominic Goodall and Marion Rastelli, eds., Tāntrikābhidhānakośa. A Dictionary of Technical Terms from Tantric Literature, vol. 3, T $-P H$ (Vienna: Verlag der Österreichischen Akademie der Wissenschaften, 2013), s.v. tantrāvatāra (pp. 77-79); Gerhard Oberhammer, Offenbahrungsgeschichte als Text: Religionshermeneutische Bemerkungen zum Phänomen in Hinduistischer Tradition (Vienna: Samlung De Nobili, 1994).

38 A precedent for this had already been set in some sense in the Mahābhārata, in the form of the "Dialogue between Umā and Maheśvara" (Umāmaheśvarasaṃvāda) of the Anuśāsanaparvan (MBh 13.126-134). It is noteworthy that an Umāmaheśvarasaṃvāda was included as part of the Sivadharma corpus in Nepal. For a preliminary study of the links between the Umāmaheśvarasamvāda of the Śivadharma and the Anuśāsanaparvan, see Florinda De Simini and Nina Mirnig, "Umā and Śiva's Playful Talks in Detail (Lalitavistara): On the Production of Śaiva Works and their Manuscripts in Medieval Nepal," in Indic Manuscripts Through the Ages, eds. Vincenzo Vergiani, Daniele Cuneo, and Camillo Formigatti (Berlin: De Gruyter, 2017), 587-653. 
Siva himself through a lineage of subsequent teachers. ${ }^{38}$ The Skandapurāna's strategy was a different one: it rather presents a complete reorientation of the Mahābhārata by turning its author into a Pāsupata ascetic. This involves a radical break with the received tradition, in particular that advocated by the Nārāyanīya. ${ }^{39}$

In the centuries to come, different religious communities developed different ways of connecting themselves with the Mahābhärata. Another telling example of this process is the Bhāgavatapurāna, which likewise presents Vyāsa as a pupil, but this time of the sage Nārada. Vyāsa asks Nārada what he had missed when he composed the Mahābhārata. Nārada tells him that he has not given due attention to the Bhagavat Vāsudeva (BhP 1.5). Vyāsa then composes the Bhāgavatapurāna about devotion to the Bhagavat, which he subsequently teaches to none other than his son Śuka, who becomes its narrator. The Bhāgavatapurāna can indeed claim to have outdone the Mahābhārata as well, having gained a special status among the Purāṇas as the central sacred scripture of Vaiṣnava communities up to the present day. ${ }^{40}$ In the end, it all serves to show the prominent position that the Mahābhārata has had as a founding epic of Brahminic lore.

39 According to two passages in the Nārāyaṇīya, Vyāsa is an incarnation of Nārāyaṇa: $M B h$ 12.334.9 and $M B h$ 12.337.3-5; 42-44. This tradition is followed in several Purānas. See Marcelle Saindon, "Quand Kṛ̣nạa Dvaipāyana Vyāsa est considéré comme un avatāra de Viṣnuu," Bulletin d'Études Indiennes 22-23 (2004-05): 307-321. The rhetorical remark in MBh 12.334.9, however, has been given a Saiva twist in $K \bar{u} P$ 1.30.67. This may reflect the influence of the Skandapurāṇa's perspective.

MBh 12.334.9:

kṛṣnadvaipāyanam vyāsaṃ viddhi nārāyaṇaṃ prabhum |

ko hy anyaḥ puruṣavyāghra mahābhāratakṛ bhavet \||

KūP 1.30.67:

kṛṣnadvaipāyanaḥ sākṣād viṣnur eva sanātanaḥ |

ko hy anyas tattvato rudraṃ vetti tam parameśvaram \|

40 On the Bhāgavatapurāna as a "new Mahābhārata," see Freda Matchett, "Some Reflections on the Frame-Narrative of the Bhāgavatapurāna," in Stages and Transitions: Temporal and Historical frameworks in Epic and Purānic Literature, ed. Mary Brockington, Proceedings of DICSEP 2 (Zagreb: Croatian Academy, 2002): 287-295. As Matchett observes (p. 290), although the Bhāgavatapurāṇa has much to say about Śuka, in line with its Kṛ̣nnaite teachings, it refrains from referring to Śuka's connection with Śiva. The connections between the Mahābhārata and the Bhāgavatapurāna have been well studied: Wendy Doniger, "Echoes of the Mahäbhārata: Why is a Parrot the Narrator of the Bhāgavata Purāna and the Devībhāgavata Purāna?" in Purāna Perennis. Reciprocity and Transformation in Hindu and Jain Texts, ed. Wendy Doniger (Albany: State University of New York Press, 1993), 31-57; Martin Christof, "The Legitimation of Textual Authority in the Bhāgavatapurāna," in Charisma and Canon. Essays on the Religious 


\section{Bibliography}

\section{Abbreviations}

BhP - Shastri, H. G., ed. The Bhāgavata [Śrīmad Bhāgavata Mahāpurāṇa]. Vol. 1, Skandas I to III. Ahmedabad: B. J. Institute of Learning and Research, 1996.

KūP - Gupta, Anand Swarup, ed. The Kūrmapurāna. Varanasi: All-India Kashiraj Trust, 1971.

MBh - Sukthankar, V. S., S. K. Belvalkar, and P. L. Vaidya, eds. The Mahābhārata for the First Time Critically Edited. Poona: Bhandarkar Oriental Research Institute, 1933.

SPI - Adriaensen, Rob, Hans T. Bakker, and Harunaga Isaacson, eds. The Skandapurāna. Vol. I, Adhyāyas 1-25. Groningen Oriental Studies, Supplement. Groningen: Egbert Forsten, 1998.

SP IV - Bisschop, Peter C. and Yuko Yokochi, eds. The Skandapurāna. Vol. IV, Adhyāyas 70-95: Start of the Skanda and Andhaka Cycles. In cooperation with Diwakar Acharya and Judit Törzsök. Groningen Oriental Studies, Supplement. Leiden: Brill, 2018.

$S P_{\mathrm{Bh}}-$ Kṛṣṇaprasāda Bhațtarāī, ed. Skandapurāṇasya Ambikākhaṇḍah.

Mahendraratnagranthamālā 2. Kathmandu: Mahendrasaṃskrțaviśvavidyālayaḥ, 1988.

\section{References}

Bakker, Hans T. "Royal Patronage and Religious Tolerance. The Formative Period of GuptaVākāțaka Culture.” Journal of the Royal Asiatic Society 20 (2010): 461-475.

Bakker, Hans T. The World of the Skandapurāna. Northern India in the Sixth and Seventh Centuries. Leiden: Brill, 2014.

Bedekar, V. M. "The Story of Śuka in the Mahābhārata and the Purānas: A Comparative Study.” Purāṇa 7 (1965): 87-127.

Bisschop, Peter C. Eary Śaivism and the Skandapurāna. Sects and Centres. Groningen: Egbert Forsten, 2006.

Bisschop, Peter C. “Śiva.” In Brill's Encyclopedia of Hinduism, vol. 1, edited by Knut Jacobsen et al., 741-754. Leiden: Brill, 2009.

Bisschop, Peter C. Universal Śaivism. The Appeasement of All Gods and Powers in the Śāntyadhyāya of the Śivadharmaśāstra. Leiden: Brill, 2018.

Bisschop, Peter C. "Vyāsa's Palimpsest. Tracking Processes of Transmission and Re-creation in Anonymous Sanskrit Literature." In Perspectives on Lived Religion: Practices Transmission - Landscape, edited by N. Starling, H. Twiston Davies, and L. Weiss, 165-172. Leiden: Sidestone Press, 2019.

History of the Indian Subcontinent, eds. Vasudha Dalmia, Angelika Malinar, and Martin Christof (New Delhi: Oxford University Press, 2001), 62-76; Kenneth R. Valpey, "The Bhāgavatapurāna as a Mahābhārata Reflection," in Parallels and Comparisons, ed. Petteri Koskikallio, Proceedings of DICSEP 4 (Zagreb: Croatian Academy, 2009), 257-277. 
Bisschop, Peter C. "Rudra-Śiva in the Nārāyaṇiya and the Rejoinder of the Skandapurāna." In The Nārāyañiya: Reconsidering an Epic and its Contexts, edited by Robert Leach and Angelika Malinar, forthcoming.

Bonazolli, Giorgio. “Purāṇic Paramparā.” Purāṇa 22 (1980): 33-60.

Brockington, John. The Sanskrit Epics. Brill: Leiden, 1998.

Cecil, Elizabeth A. "Mapping the Pāśupata Landscape: Narrative, Tradition, and the Geographic Imaginary." The Journal of Hindu Studies 11 (2018): 285-303.

Christof, Martin. "The Legitimation of Textual Authority in the Bhāgavatapurāna." In Charisma and Canon. Essays on the Religious History of the Indian Subcontinent, edited by Vasudha Dalmia, Angelika Malinar, and Martin Christof, 62-76. New Delhi: Oxford University Press, 2001.

Colas, Gérard. "Bhāgavatas." In Brill's Encyclopedia of Hindusim, vol. 3, edited by Knut Jacobsen et al., 295-301. Leiden: Brill, 2011.

Couture, André. "The Harivamśa: A Supplement to the Mahābhārata." Journal of Vaishnava Studies 4, no. 3 (1996): 127-138.

De Simini, Florinda. Of Gods and Books. Ritual and Knowledge Transmission in the Manuscript Cultures of Premodern India. Berlin: De Gruyter, 2016.

De Simini, Florinda, and Nina Mirnig. “Umā and Śiva's Playful Talks in Detail (Lalitavistara): On the Production of Śaiva Works and Their Manuscripts in Medieval Nepal." In Indic Manuscripts Through the Ages, edited by Vincenzo Vergiani, Daniele Cuneo, and Camillo Formigatti, 587-653. Berlin: De Gruyter, 2017.

Doniger, Wendy. "Echoes of the Mahābhärata: Why Is a Parrot the Narrator of the Bhägavata Purāna and the Devībhāgavata Purāna?" In Purāna Perennis. Reciprocity and Transformation in Hindu and Jain Texts, edited by Wendy Doniger, 31-57. Albany: State University of New York Press, 1993.

Fitzgerald, James L. "The Many Voices of the Mahābhārata." Journal of the American Oriental Society 123, no. 4 (2003): 803-818.

Fitzgerald, James L. "Mahābhārata." In Brill's Encyclopedia of Hinduism, vol. 2, edited by Knut Jacobsen et al., 72-94. Leiden: Brill, 2010.

Goodall, Dominic, and Marion Rastelli, eds. Tāntrikābhidhānakośa. A Dictionary of Technical Terms from Tantric Literature. Vol. 3, T-PH. Vienna: Verlag der Österreichischen Akademie der Wissenschaften, 2013.

Granoff, Phyllis. "Saving the Saviour: Śiva and the Vaișnava Avatāras in the Early Skandapurāṇa." In Origin and Growth of the Purānic Text Corpus. With Special Reference to the Skandapurāna, edited by Hans T. Bakker, 111-138. Papers of the 12th World Sanskrit Conference 3.2. Delhi: Motilal Banarsidass, 2004.

Grünendahl, Reinhold. Viṣnudharmāh. Precepts for the Worship of Viṣnu. 3 vols. Wiesbaden: Harrassowitz, 1983-1989.

Grünendahl, Reinhold. “Zur Stellung des Nārāyaṇīya im Mahābhārata.” In Nārāyaṇīya-Studien, edited by Peter Schreiner, 197-240. Wiesbaden: Harrassowitz, 1997.

Grünendahl, Reinhold. "On the Frame Structure and 'Sacrifice Concept' in the Nārāyaṇīya and Tirthayātrā Sections of the Mahābhārata, and the Craft of Citation." Zeitschrift der Morgenländischen Gesellschaft 152, no. 2 (2002): 309-340.

Hegarty, James. "What Need Has He of the Waters of Puṣkara? The Narrative Construction of tīrtha in the Sanskrit Mahābhārata." In Battle, Bards and Brāhmins, edited by John Brockington, 129-156. Papers of the 13th World Sanskrit Conference 2. Delhi: Motilal Banarsidass, 2012. 
Hiltebeitel, Alf. Rethinking the Mahābhärata. A Reader's Guide to the Education of the Dharma King. Chicago: Chicago University Press, 2001.

Hiltebeitel, Alf. "Mokșa and Dharma in the Mokșadharma." Journal of Indian Philosophy 45 (2017): 749-766.

Jaffee, Martin S. "Rabbinic Authorship as a Collective Enterprise." In The Cambridge Companion to the Talmud and Rabbinic Literature, edited by Charlotte Elisheva Fonrobert and Martins S. Jaffee, 17-37. New York: Cambridge University Press, 2007.

Lévi, Sylvain. "Tato jayam udirayet." Translated by L. G. Khare. Annals of the Bhandarkar Oriental Research Institute 1, no. 1 (1918-19): 13-20.

MacKenzie Brown, C. "Modes of Perfected Living in the Mahābhārata and the Purānas: The Different Faces of Śuka the Renouncer." In Living Liberation in Hindu Thought, edited by Andrew 0. Fort and Patricia Y. Mumme, 157-183. Albany: State University of New York Press, 1996.

Mallinson, James, and Mark Singleton. Roots of Yoga. London: Penguin, 2017.

Mann, Richard. The Rise of Mahāsena. The Transformation of Skanda-Kārttikeya in North India from the Kuṣāna to Gupta Empires. Leiden: Brill, 2012.

Matchett, Freda. "The Harivaḿ̧a: Supplement to the Mahābhārata and Independent Text." In Journal of Vaishnava Studies 4, no. 3 (1996): 139-150.

Matchett, Freda. "Some Reflections on the Frame-Narrative of the Bhāgavatapurāna." In Stages and Transitions: Temporal and Historical Frameworks in Epic and Purāṇic Literature, edited by Mary Brockington, 287-295. Proceedings of DICSEP 2. Zagreb: Croatian Academy, 2002.

Oberhammer, Gerhard. Offenbahrungsgeschichte als Text: Religionshermeneutische Bemerkungen zum Phänomen in Hinduistischer Tradition. Vienna: Samlung De Nobili, 1994.

Pollock, Sheldon. The Language of the Gods in the World of Men. Berkeley: University of California Press, 2006.

Rocher, Ludo. The Purānas. A History of Indian Literature 2.3. Wiesbaden: Harrassowitz, 1986.

Saindon, Marcelle. "Quand Kṛ̦̣na Dvaipāyana Vyāsa est considéré comme un avatāra de Vișnu." Bulletin d'Études Indiennes 22-23 (2004-05): 307-321.

Scheuer, Jacques. Śiva dans le Mahābhārata. Paris: Presses Universitaires de France, 1982.

Schreiner, Peter. "Yoga - Lebenshilfe oder Sterbetechnik?” In Hinduismus-Reader, edited by Angelika Malinar, 137-148. Göttingen: Vandenhoeck \& Ruprecht, 2009.

Shulman, David. The Hungry God. Hindu Tales of Filicide and Devotion. Chicago: University of Chicago Press, 1993.

Smith, John. The Mahābhārata. An Abridged Translation. London: Penguin, 2009.

Sullivan, Bruce. Kṛ̦ṇa Dvaipāyana Vyāsa and the Mahābhārata: A New Interpretation. Leiden: Brill, 1990.

Valpey, Kenneth R. “The Bhāgavatapurāṇa as a Mahābhārata Reflection.” In Parallels and Comparisons, edited by Petteri Koskikallio, 257-277. Proceedings of DICSEP 4. Zagreb: Croatian Academy, 2009.

White, David Gordon. “Utkrānti: From Epic Warrior’s Apotheosis to Tantric Yogi’s Suicide.” In Release from Life - Release in Life. Indian Perspectives on Individual Liberation, edited by Andreas Bigger et al., 291-302. Bern: Peter Lang, 2010.

Witzel, Michael. "On the Origin of the Literary Device of the 'Frame Story' in Old Indian Literature.” In Hinduismus und Buddhismus. Festchrift für Ulrich Schneider, edited by Harry Falk, 380-414. Freiburg: Hedwig Falk, 1987. 